\title{
COMPARATIVE EFFECT OF CURARE AND SUCCINYLCHOLINE ON SURVIVAL TIME OF SHOCKED RATS*
}

\author{
Felisaring G. Daos, M.d. $\dagger$
}

A PATIENT who had been severely traumatized in an automobile accident needed anaesthesia for an exploratory laparotomy. It was believed that her spleen had been ruptured. She was put to sleep with a few breaths of cyclopropane, and 40 $\mathrm{mg}$. of succinylcholine were given intravenously. Within a few seconds she went into circulatory collapse. In spite of infusion of blood under pressure into three different veins simultaneously, she expired. She was found to have a ruptured liver as well as a ruptured spleen. Because of the sudden circulatory collapse on administration of succinylcholine, the question arose as to whether the collapse might have been enhanced by the relaxing agent. The possibility was mentioned that curare might have been better.

Accordingly, experiments were carried out to determine the effect of each of these relaxing agents. under conditions of shock.

\section{METHOD}

Wistar strain fèmale white rats weighing between 190 and $210 \mathrm{gm}$. were shocked according to the method of Smith, Williams, Blood, and D'Amour. ${ }^{1}$ Briefly, this entails anaesthetizing the animals with pentobarbital, cannulating the trachea to ensure a patent airway, and pinching the cecum of the rats 3 times per sec. for $15 \mathrm{~min}$. with a standardized pressure. One hundred per cent of the animals die, and the time of survival is a measure of the resistance of the rat to the stress.

A control group included 30 animals who were given 0.4 c.c. of normal saline intravenously to equalize fluid injections.

A second group of control animals was anaesthetized, shocked, and given 0.4 c.c. of normal saline intravenously. They were then given artificial respiration with oxygen using a "windshield wiper" respirator. Survival time was noted.

A third group of animals was given succinylcholine $1.0 \mathrm{mg} . / \mathrm{kg}$. intravenously after the shocking procedure. Artificial respiration was utilized.

The fourth group of animals was treated the same as the third except that d-tubocurarine $0.3 \mathrm{mg} . / \mathrm{kg}$. was administered in place of the succinylcholine given the third group.

\section{REșults}

Table I shows that there was no significant difference in survival times of the

*Supported by a grant from the Burroughs Wellcome Company.

$\dagger$ Division of Anesthesiology, University of Colorado Department of Medicine, Denver, Colorado. 402

Can. Anaes. Soc. J.. vol. 8, no. 4, July, 1961 
TABLE I

Comparative Effect of Curare and Succinylcholine on Survival Time of SHOCKED RATS

\begin{tabular}{cllll}
\hline \hline No. of rats & \multicolumn{2}{c}{ Procedure after shock } & $\begin{array}{c}\text { Average survival time } \\
\text { (min.) }\end{array}$ \\
\hline 30 & Normal saline & Spontaneous respiration & 175 & $\mathrm{~A}$ \\
20 & Normal saline & Artificial respiration & 200 & $\mathrm{~B}$ \\
24 & Succinylcholine & Artificial respiration & 216 & $\mathrm{C}$ \\
10 & Curare & Artificial respiration & 178 & $\mathrm{D}$ \\
\hline
\end{tabular}

$A-B$, not significant; $A-D$, not significant; $B-C$, not significant; $B-D$, not significant; $\mathrm{C}-\mathrm{D}$, not significant; $\mathrm{A}-\mathrm{C}, p=0.01$.

control as compared to either group of rats which had had relaxing agents. Neither was there a significant difference between the two groups of experimental animals although the animals receiving curare had a somewhat shorter average time of survival. The only statistical significant value occurred with a shorter survival of animals who had no artificial respiration compared to those who had succinylcholine and artificial respiration $(p-0.01$.$) .$

\section{Discussion}

Most evidence presented to date ipdicates that administration of succinylcholine is followed by a transient rise of blood pressure. ${ }^{2}$ This information has come from healthy patients and animals. It would not be inconceivable that results using shocked subjects might afford different responses. The rat seemed to be a good subject because its response to a definite dose of succinylcholine is quite similar to, and its average concentration of cholinesterase is reported to be somewhat higher than, that of a human being. ${ }^{3}$

Clinical doses of curare do not have untoward effects on the circulatory system, although large doses are known to be ganglionic blocking agents. If animals are not healthy, it is again not inconceivable that relatively-small doses might produce untoward effects.

Data obtained in these experiments reveal no definite choice of relaxing agent to be used in cases of shock. Since there was no significant difference in survival time of controls as compared to the animals receiving relaxant drugs, one has no evidence from this work that the circulatory collapse of the patient whose demise stimulated these experiments was enhanced by the choice of relaxing agent.

\section{SUMMARY}

Rats were shocked by pinching the cecum, a method which produces 100 per cent mortality. Time of survival using artificial respiration was noted. Another group of animals was treated similarly, except that succinylcholine was administered immediately following the shocking procedure. Still another group was studied using curare rather than succinylcholine. No statistically significant differences in survival time were found between any of the three groups. 


\section{RÉSUMÉ}

Un malade traumatisé a été soumis à l'anesthésie avec une dose minima de cyclopropane, et on lui a administré de la succinylcholine. Quelques secondes après l'administration de ce succinylcholine, il est apparu un collapse circulatoire. La question s'est posée: chez un malade en état de choc, serait-il préférable de donner du curare ou de la succinylcholine.

C'est dans le but d'obtenir des renseignements sur ce sujet que nous avons fait des recherches.

On a employé comme témoins des rats, anesthésiés au nembutal, chez qui on provoquait un état de choc en leur faisant subir un traumatisme intestinal, ce qui entraînait la mort dans un temps limité. A un second groupe de rats traités de la même façon, on a administré par voie endoveineuse, aussitôt le choc installé, de la succinylcholine à raison de $1 . \mathrm{mg} . / \mathrm{kg}$. A un troisième groupe traité comme le premier, l'on a donné par voie endovieneuse, aussitôt le choc installé, du curare à raison de $3 \mathrm{mg}$. par kilo. On n'a pas noté de différence appréciable dans le temps de survie entre les animaux qui ont reçu de la succinylcholine et ceux qui ont reçu du curare.

\section{REFERENCES}

1. Smith, D. L.; Williams, W. J.; Blood, F. R.; \& D'Amolr, F. E. Traumatic Shock in the Albino Rat. Am. J. Physiol. 165: 532 (1951).

2. Wycoff, C. C. Endotracheal Intubation: Effects on Blood Pressure and Pulse rate. Anesthesiology $21: 153$ (1960).

3. ZAJicek, J., \& DatTA, N. Investigation on the Acetylcholinesterase Activity of Erythrocytes, Platelets and Plasma in Different Animal Species. Acta Haemat. 9: 115 (1953). 